\title{
福島第一原子力発電所事故後の水道水摂取制限による 乳児の回避線量評価
}

\author{
木名瀬 栄 ${ }^{1 *}$, 木村 仁宣 ${ }^{1}$, 高原 省五 $^{1}$, 本間 俊充 $^{1}$ \\ Evaluation of Averted Doses to Infants by Tap Water Restrictions after \\ the Fukushima Daiichi Nuclear Power Plant Accident \\ Sakae KINASE ${ }^{1, *}$, Masanori KIMURA ${ }^{1}$, Shogo TAKAHARA ${ }^{1}$ and Toshimitsu HOMMA ${ }^{1}$ \\ ${ }^{1}$ Nuclear Safety Research Center, Japan Atomic Energy Agency, 2-4 Shirane, Shirakata, Tokai-mura, Naka-gun, Ibaraki 319-1195, Japan
}

(Received April 28, 2011 and accepted in revised form June 14, 2011)

\begin{abstract}
There has been some concern in reviewing the effectiveness of making decisions on the implementation of protective measures in emergency exposure situations. After the Fukushima Daiichi nuclear power plant accident, temporal changes in the concentration of iodine 131 in tap water were studied using published data from several authorities in Fukushima, Ibaraki, and Tokyo. Averted doses to infants (1-year-old children) due to the intake of iodine 131 through tap water restrictions were also evaluated. Consequently, it was found that the apparent half-life of iodine 131 in tap water was 2.8 days. The averted equivalent doses to the thyroids of 1-year-old children were found to have a maximum value of $8.3 \mathrm{mSv}$ in a local area of Fukushima. Hence, the tap water restrictions implemented by the authorities were considered to be effective in the early phase of the emergency exposure situation.
\end{abstract}

\section{KEYWORDS: Fukushima, nuclear accident, iodine, tap water, infant, thyroid, dose}

\section{I. 緒 言}

2011年 3 月 11 日に発生した福島第一原子力発電所事故 の影響により, 福島県を始め荻城県, 東京都などの広い地 域において，放射性ヨウ素131(以下， ${ }^{131} \mathrm{I}$ )などに関する 水道水摂取制限が行われた。しかし, 水道水の摂取制限解 除については, 解除の細かな規定がなく, 判断は水道を運 営する自治体に委ねられ，社会的な混乱を招いた。こうし た状況を踏をえると, 水道水による無用な被ばくや制限 · 混乱を回避する, 適切な防護措置の検討には, 水道水中 ${ }^{131} \mathrm{I}$ 濃度変化の特徵を調べるとともに，水道水の摂取制限 による回避線量, すなわち防護措置の効果を評価すること が重要であると考える。本研究では, 今後の水道水摂取制 限解除の基準策定検討に資するため, 福島第一原子力発電 所事故に直接影響した, 福島県, 茨城県, 東京都の水道水 中 ${ }^{131} \mathrm{I}$ の濃度变化を調べるとともに，水道水の摂取制限に よる乳児(1 歳)の回避線量を評価した。

\footnotetext{
1 独日本原子力研究開発機構 安全研究センター

* Corresponding author, E-mail: kinase.sakae@jaea.go.jp

C) 2011 Atomic Energy Society of Japan, All Rights Reserved.
}

\section{II. 厚生労働省の乳児による水道水摂取に 関わる対応}

厚生労働省は, 2011年 3 月 19 日, 対象となる自治体に 対し, 原子力安全委員会が定めた水道水摂取制限指標值 （放射性ヨウ素 : $300 \mathrm{~Bq} / \mathrm{kg}$ ) を通知した。また，2011年 3 月21日, 食品衛生法に基づく暫定規制値の整合性を鑑 み, 水道水中放射性ヨウ素が $100 \mathrm{~Bq} / \mathrm{kg}$ を超える場合に は, 乳児用調整粉乳を水道水で溶かして乳児に与える等, 乳児による水道水の摂取を控えるよう, 再度通知をした。 2011年 4 月 4 日には, 水道水の摂取制限解除時期につい て, 直近の 3 日間の水道水中放射性ヨウ素濃度の平均值 が基準を下回るとともに，值が減少傾向になることとした。

\section{III. 自治体の乳児による水道水摂取に 関わる対応}

福島県, 茨城県, 東京都の自治体は, 原子力安全委員会 や厚生労働省の基準に基づき, 乳児の水道水摂取制限を行 い, その後自治体独自の判断により, その解除を行った (Table 1)。東京都の乳児の水道水摂取制限は, 2011年 3 月 22 日に採水された金町浄水場の $210 \mathrm{~Bq} / \mathrm{kg}$ が要因とな 
った。

\section{IV. 方 法}

厚生労働省, 東海村役場, 東京都庁が公表したデータ1) を用いて，福島県 5 自治体 (飯舘村滝下浄水場，郡山市豊 田町地内, 川俣町字桶の口地内, 南相馬市南相馬合同庁 舎, いわき市いわき合同庁舎), 茨城県東海村外宿浄水 場，東京都新宿区百人町で採取された水道水の ${ }^{131} \mathrm{I}$ 濃度変 化を調べた。調查の対象期間は，2011年 3 月 16 日〜 4 月 16日までの 1 月間とした(飯舘村については，2011年 5 月 10 日まで)。また, 水道水中 ${ }^{131} \mathrm{I}$ 濃度と乳児 (1 歳) 91 日 当たりの摂水量から, 乳児(1 歳)の 1 日当たりの ${ }^{131} \mathrm{I}$ 摂取 量を算定し， ${ }^{131}$ 摂取量に国際放射線防護委員会 (ICRP) Publication $\left.67^{2}\right)$ の線量係数を乗じることにより，乳児 (1 歳)の甲状腺等価線量と実效線量を評価した。乳児の摂水 量は, 国際原子力機関 (IAEA) Safety Series No. 813) に示 される值を参考に, 1 日当たり $1.4 \times 10^{3} \mathrm{~mL}$ と仮定した。

Table 2 に， ${ }^{131} \mathrm{I}$ の線量係数を示す。な押, 調査期間中, 水道水サンプリングが実施されなかった日については，そ

Table 1 Tap water restrictions implemented by the authorities

\begin{tabular}{ccccc}
\hline Prefectures & Authority & The first day & The last day & Days \\
\hline Fukushima & Iitate & March 21st & May 10th & 50 \\
& $\begin{array}{c}\text { Koriyama, } \\
\text { Kawamata }\end{array}$ & March 22nd & March 25th & 3 \\
& Minamisoma & March 22nd & March 30th & 8 \\
& Iwaki & March 23rd & March 31st & 8 \\
Ibaraki & Tokai & March 23rd & March 26th & 3 \\
Tokyo & $\begin{array}{c}\text { The 23 wards } \\
\text { and 5 cities }\end{array}$ & March 23rd & March 24th & 1 \\
& & & \\
\hline
\end{tabular}

の前後日のサンプリング測定評価值のうち高い值を用いて 線量評価を行った。水道水中 ${ }^{131} \mathrm{I}$ が検出されなかった日に ついては，有意な被ばくがないこととした。

\section{V.結果および考察}

Figure 1 に, 福島県 5 自治体 (飯舘村, 郡山市, 川俣 町, 南相馬市, いわき市), 茨城県東海村, 東京都新宿区 で観測された水道水中 ${ }^{131} \mathrm{I}$ 濃度変化を示す。図に示すよう に, 水道水中 ${ }^{131} \mathrm{I}$ 濃度は, サンプリング地点によって異な り, 福島第一原子力発電所から約 $230 \mathrm{~km}$ 離れた東京都新 宿区では，2011年 3 月 26 日の $37.2 \mathrm{~Bq} / \mathrm{kg}$ を最大值とし た。東京都の水道水中 ${ }^{131} \mathrm{I}$ 濃度は, 福島県各地, 茨城県東 海村の值に比べ低く, 福島第一原子力発電所事故の影響が 直ちに及ぼされるものではないことが確認された。全体的 な傾向としては, 福島県内各地域, 茨城県東海村, 東京都 新宿区いずれの地点においても, 福島第一原子力発電所事 故後, 時間が経つとともに減少している。水道水中 ${ }^{131} \mathrm{I}$ 濃 度変化の減少割合は, 見掛けの半減期が $2.8 \pm 1.2$ 日程度と なり， ${ }^{131} \mathrm{I}$ の物理的半減期である 8.0 日よりも早い。こう した傾向は, 調査開始日の 2011 年 3 月 16 日以降, 当該地 域に抢いて, ${ }^{131} \mathrm{I} の$ 追加の降下量が少なく, 環境中の希釈 効果が大きく寄与したものと考える。2011年 4 月 1 日以 降, 福島県飯舘村, 郡山市, 南相馬市, 茨城県東海村, 東

Table 2 Ingestion dose coefficients for ${ }^{131} \mathrm{I}(\mathrm{Sv} / \mathrm{Bq})$

\begin{tabular}{ccc}
\hline Age of intakes & Thyroid equivalent dose & Effective dose \\
\hline 1-year-old children & $3.6 \times 10^{-6}$ & $1.8 \times 10^{-7}$ \\
Adulta) & $4.3 \times 10^{-7}$ & $2.2 \times 10^{-8}$ \\
\hline
\end{tabular}

a) for reference.

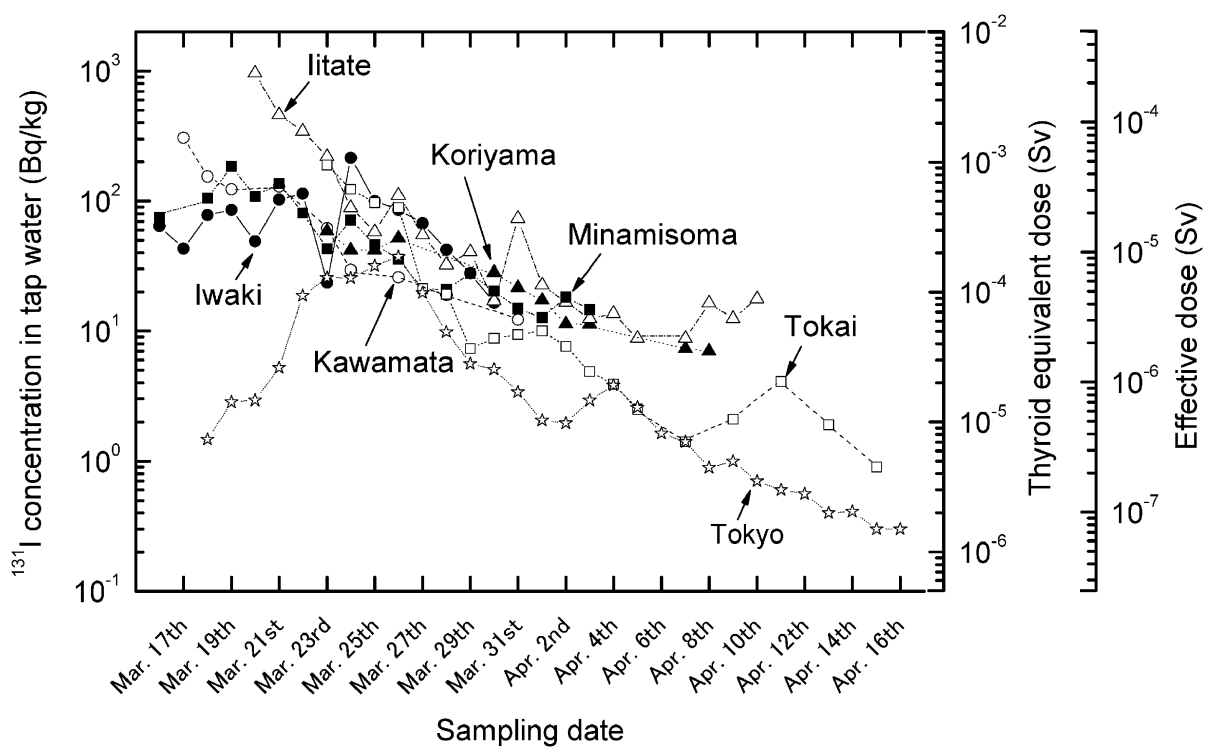

Fig. 1 Concentration of ${ }^{131} \mathrm{I}$ in tap water, projected equivalent doses to the thyroids and projected effective doses of 1-year-old children due to intakes of ${ }^{131} \mathrm{I}$ in tap water at some local areas of Fukushima, Tokai and Tokyo 
Table 3 Averted doses to 1-year-old children due to intakes of ${ }^{131} \mathrm{I}$ by tap water restrictions $(\mathrm{Sv})$

\begin{tabular}{ccc}
\hline Authority & Thyroid equivalent dose & Effective dose \\
\hline Iitate, Fukushima & $8.3 \times 10^{-3}$ & $4.1 \times 10^{-4}$ \\
Koriyama, Fukushima & $5.1 \times 10^{-4}$ & $2.5 \times 10^{-5}$ \\
Kawamata, Fukushima & $1.1 \times 10^{-3}$ & $5.6 \times 10^{-5}$ \\
Minamisoma, Fukushima & $1.7 \times 10^{-3}$ & $8.7 \times 10^{-5}$ \\
Iwaki, Fukushima & $2.9 \times 10^{-3}$ & $1.5 \times 10^{-4}$ \\
Tokai, Ibaraki & $2.1 \times 10^{-3}$ & $1.0 \times 10^{-4}$ \\
Shinjyuku, Tokyo & $1.3 \times 10^{-4}$ & $6.5 \times 10^{-6}$ \\
\hline
\end{tabular}

京都新宿区においては, 水道水中に低濃度の ${ }^{131} \mathrm{I}$ が検出さ れている。これは，土䁃中などの沈着物や再浮遊物が，雨 水などとともに水道水の原水に流入されたものと推察す る。調查期間中, 最も高い值を示したのは, 飯舘村 (965 $\mathrm{Bq} / \mathrm{kg}$ )であった。

また，Fig. 1 は乳児の甲状腺等価線量, 実効線量の変化 も示している。いずれの線量も, 水道水中 ${ }^{131} \mathrm{I}$ 濃度変化に 応じて, 時間が経つとともに, 減少傾向になった。なお, 実際の乳児の長期間 ${ }^{131} \mathrm{I}$ 連続慢性摂取の場合, 摂取と排泄 のバランスにより, 甲状腺や体内中の ${ }^{131} \mathrm{I}$ はビルドアップ され平衡值 $(=$ (実効半減期 (日) $) \times(1$ 日当たりの一定の摂 取量) $/ \ln 2)$ になることが推定されるため, 甲状腺等価線 量, 実効線量は, 日ごとに評価した線量の総和より小さく なることが考えられる。

各自治体の乳児の水道水拱取制限による回避線量を Table 3 に示す。緊急時被ばく状況が継続する中, 自治 体, 特に福島県飯舘村に抢いて, 乳児の水道水摂取制限 は, 甲状腺等価線量 $8.3 \mathrm{mSv}$, 実効線量 $4.1 \times 10^{-1} \mathrm{mSv}$ を回避し, 残存線量を低減化する有効な手段となった。 131I はもとより，放射性セシウム137やその他の放射性核 種による内部被ばくの恐れがある状況において, 厚生労働
省の乳児の飲料水摂取制限は, 乳児の甲状腺等価線量, 実 効線量を低くする防護措置として正当化されるものと考え る。また, 茨城県東海村などでは, 地震による停電や水道 管復旧作業のため, 水道水の供給が遅れた。この水道水供 給の遅延により, 偶然にも水道水中 ${ }^{131} \mathrm{I}$ による被ばくを減 らすことができた。水道水摂取制限の期間が短く, 水道水 中 ${ }^{131} \mathrm{I}$ が低濃度であった東京都新宿区では, 乳児の回避甲 状腺等価線量は $1.3 \times 10^{-1} \mathrm{mSv}$ となった。

\section{VI. 結 論}

福島第一原子力発電所事故後の, 福島県, 茨城県, 東京 都の水道水中 ${ }^{131} \mathrm{I}$ 濃度変化について調べた。また, 水道水 中 ${ }^{131} \mathrm{I}$ による乳児の甲状腺等価線量, 実効線量を評価する とともに, 自治体の摂取制限による回避線量を算定した。 その結果, 水道水中 ${ }^{131} \mathrm{I}$ 濃度は, 水道水のサンプリング地 点に大きく影響され, 見掛けの半減期 2.8 日程度で減少す ることがわかった。今回の福島第一原子力発電所に関わる 水道水摂取制限は, 甲状腺等価線量の低減に有効であり, 福島県飯舘村では約 $8.3 \mathrm{mSv}$ の乳児の回避甲状腺等価線 量になった。

\section{一参考文献一}

1) Ministry of Health, Labour and Welfare, Information about the Great East Japan Earthquake, Online, Available: http://www. mhlw.go.jp/english/topics/2011eq/index.html (2011, April 17).

2) ICRP, Age-dependent Doses to Members of the Public from Intake of Radionuclides: Part 2 Ingestion Dose Coefficients, ICRP Publication 67, Pergamon Press, Oxford (1993).

3) IAEA, Derived Intervention Levels for Application in Controlling Radiation Doses to the Public in the Event of a Nuclear Accident or Radiological Emergency, IAEA, Vienna, Safety Series No. 81, IAEA, Vienna (1986). 